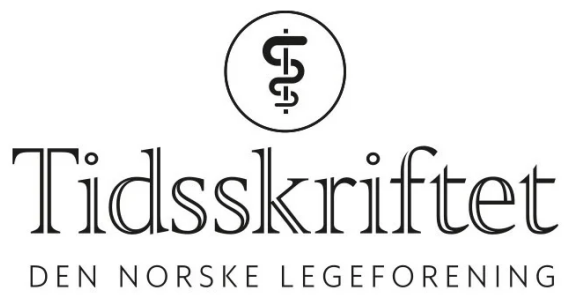

\title{
Bortkastet tid?
}

TIDLIGERE I TIDSSKRIFTET

JULIE DIDRIKSEN

julie.didriksen@tidsskriftet.no

Tidsskriftet

I Tidsskriftets utgave 34/35/36 i 1980 dukket det opp et lite dikt i Korrespondanser-spalten, med en dyster påminnelse om at man må leve i nuet, for hver dag kan være den siste (Tidsskr Nor Lægeforen 1980; 100: 2089).

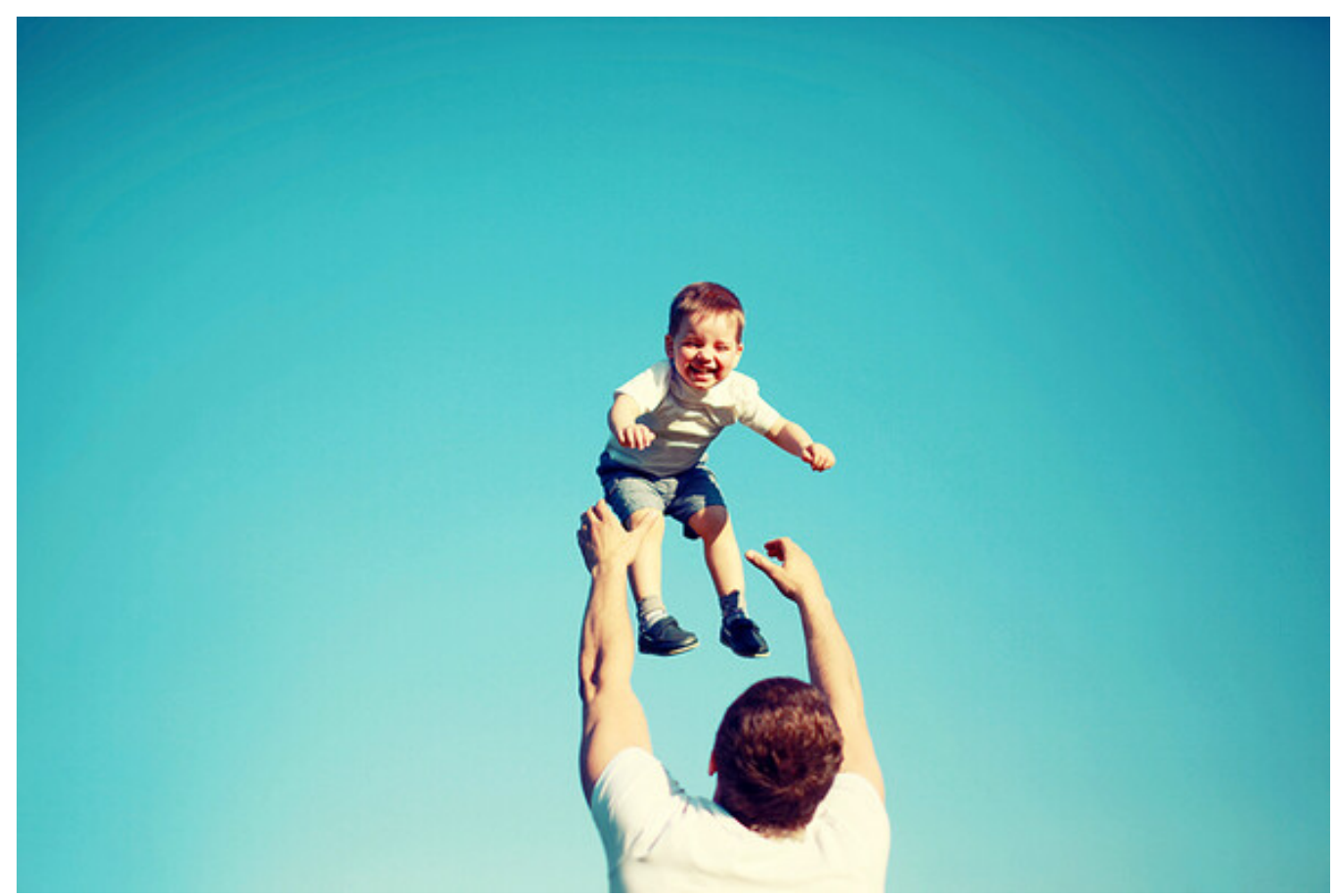

Illustrasjon: Guasor/iStock

Bortkastet tid -

- Dette

er bortkastet tid,

sa min alltid 
travle venn

som lå på sykehuset

og ikke visste

at

han snart skulle dø-

og at den tiden

som var igjen

var den viktigste i hans liv.

Allan Aarflot

Publisert: 10. desember 2021. Tidsskr Nor Legeforen. DOI: 10.4045/tidsskr.21.0496

(C) Tidsskrift for Den norske legeforening 2023. Lastet ned fra tidsskriftet.no 26. april 2023. 